\title{
INHIBITORY EFFECT OF ETHANOLIC EXTRACT OF CURANGA FEL-TERRAE (PUGUN TANO) LEAVES ON ACETYLCHOLINE MUSCARINIC-3 RECEPTORS INDUCED ON ISOLATED GUINEA PIG TRACHEAL
}

\author{
URIP HARAHAP ${ }^{1}$, DADANG IRFAN HUSORI ${ }^{*}$, MARIANNE ${ }^{1}$, SRI YULIASMI ${ }^{2}$, POPI PATILAYA ${ }^{3}$, LIA LAILA ${ }^{4}$, \\ BAYU EKO PRASETYO ${ }^{4}$, HENNY SRI WAHYUNI ${ }^{2}$, IMAM BAGUS SUMANTRI ${ }^{1}$
}

${ }^{1}$ Department of Pharmacology, Faculty of Pharmacy, Universitas Sumatera Utara, Medan, Indonesia. ${ }^{2}$ Department of Pharmaceutical Chemistry, Faculty of Pharmacy, Universitas Sumatera Utara, Medan, Indonesia. ${ }^{3}$ Department of Pharmaceutical Biology, Faculty of Pharmacy, Universitas Sumatera Utara, Medan, Indonesia. ${ }^{4}$ Department of Pharmaceutical Technology, Faculty of Pharmacy, Universitas Sumatera Utara, Medan, Indonesia. Email: dadang@usu.ac.id

Received: 18 July 2016, Revised and Accepted: 29 September 2016

\section{ABSTRACT}

Objective: The study was aimed to investigate the inhibitory effect of ethanolic extract of Curanga fel-terrae leaves (EECFL) against acetylcholine (ACh)-induced contraction of the ACh-muscarinic-3 receptor.

Materials and Methods: The study of the inhibitory effect of the ethanolic extract on the contraction by ACh concentration series $\left(10^{-8}-10^{-3} \mathrm{M}\right)$ was conducted in vitro using isolated guinea pig tracheal organ in the Krebs solution.

Results: Early incubation of tracheal organ with EECFL $(0.5,1,2$ and $4 \mathrm{mg} / \mathrm{ml})$ before contracted by the series of ACh concentration produces the decrease of ACh contraction. The concentration series of ACh sigmoid curve rightward shift without decreasing the maximal contraction. The results of double-reciprocal plot of ACh shows the mean value of the $1 / \mathrm{y}$-intercept of each extract was not different with the control.

Conclusion: The EECFL showed competitive antagonist effect on ACh-muscarinic-3 receptors.

Keywords: Curanga fel-terrae, Pugun tano, Acetylcholine-muscarinic-3 receptors, Competitive antagonist, Ethanolic extract.

(C) 2017 The Authors. Published by Innovare Academic Sciences Pvt Ltd. This is an open access article under the CC BY license (http://creativecommons. org/licenses/by/4. 0/) DOI: http://dx.doi.org/10.22159/ajpcr.2017.v10i1.14163

\section{INTRODUCTION}

Curanga fel-terrae (Lour.) Merr. in Indonesia known as pugun tano is one of the plants of the family Linderniaceae. This plant is found in Asia such as China, India, Indonesia, Philippine, Malaysia, and Myanmar In Indonesia, the plant can be found in Sumatra, Java, Kalimantan, and Maluku [1]. Rural communities use the leaves and latex to cure abdominal pain, cough, scabies, bruising, inflammation, and asthma Previous research suggests that these plants contain glycosides [2,3], flavonoids [4], saponins [5], terpenoids, curangin, and bitter substances [6]. C. fel-terrae has been studied have a pharmacological activity as anthelmintic [7], antidiabetic [8,9], antibreast cancer [10-12], diuretic effect [13], and cardioprotective effect [14].

Epidemiology study showed almost 20\% people in the world suffer from diseases associated with allergy and asthma [15]. Almost 300 million people suffer from asthma, especially asthma which related to allergy. The main risk factors of asthma in developed and poor countries is caused by allergies and respiratory tract irritation induced by allergens and particles in the air [16]. The respiratory diseases such as asthma, chronic bronchitis, and emphysema were the fourth reason of death in Indonesia [17].

Important nervous system associated with human lung is the cholinergic nervous system. Cholinergic or parasympathetic nervous system was largely expressed in the proximal airways and decreases toward the periphery. Acetylcholine (Ach) released by the parasympathetic system plays an important role in controlling the airways and mucus release from submucosal glands, as well as goblet cells in the airway epithelium [18]. In human airway muscarinic receptors overexpressed in $M_{1}, M_{2}$, and $M_{3}$ types $[18,19]$. Excessive activation on the cholinergic nerve can cause of respiratory tract disorders [20].

Indonesia has great biodiversity that potential for the discovery of new drugs. Therefore, it is possible to find a new alternative treatment for asthma from natural resources. Although C. fel-terrae has been used traditionally by the community as a medicine such as for asthma, the scientific data associated with pharmacological activity reports still lack.

Based on this reason, researchers are interested in evaluating the ethanolic extract of $C$. fel-terrae leaves (EECFL) in the respiratory tract primarily on the contraction induced by ACh on ACh receptorsmuscarinic-3.

\section{MATERIALS AND METHODS}

Materials

Drugs and chemicals used in this study were ACh, dimethyl sulfoxide (Sigma-Aldrich, USA), and ethanol 96\% (Merck). Instrument used in this experiment was organ bath PowerLab (ML0146/50, PanLab, ADInstruments, New Zealand).

Preparation of extract

C. fel-terrae (pugun tano) was collected from Pancur Batu, Deli Serdang District, Sumatera Utara and identified by Indonesian Institute of Sciences. The leaves were washed and dried at $30-35^{\circ} \mathrm{C}$, then grinded until dried powder was obtained. The dried powder was percolated using ethanol $96 \%$ then the obtained percolate was evaporated and freeze-dried. 
Tissue preparation

Male guinea pig weighing 300-500 g (3-4 months) were housed in a room with controlled temperature and lighting and allowed free access to chow and water. The animals were sacrificed by cervix dislocation Trachea was dissected out and the connective tissue was gently removed. Subsequently, the rings were cut with a length of 8-9 rings and both sides cartilage was bound with which connected to the transducer MLT0201 (PanLab, ADInstrument) connected with PowerLab T150676 (PanLab, ADInstrument) [21-23].

Inhibitory effect of EECFL to the contraction induced by agonist ACh-muscarinic- 3 receptor

After equilibration, guinea-pig tracheal was contracted gradually with series concentration of ACh $\left(10^{-8}-10^{-3} \mathrm{M}\right)$ to the tissue bath as a control concentration-response curve until maximum contraction was achieved. Subsequently, ACh was washed out of the bath and complete relaxation of tracheal allowed. The ability of EECFL to challenge AChinduced tracheal contraction was tested using cumulative addition of ACh after 20 minutes preincubation of the tracheal with extract $(0.5 \mathrm{mg} / \mathrm{ml}, 1 \mathrm{mg} / \mathrm{ml}, 2 \mathrm{mg} / \mathrm{ml}, 4 \mathrm{mg} / \mathrm{ml})$ or with control. All the experiment conducted using Krebs buffer with gas flowing $\mathrm{O}_{2}: \mathrm{CO}_{2}$ (95\%: 5\%) [21-23].

\section{Calculation of responses and data presentation}

The highest contraction induced by ACh was considered the maximum response. Log concentration-response (LCR) curves were constructed. The effects of different concentrations of EECFL were expressed as a percentage of maximum inhibitory response $(100 \%) . \mathrm{R}_{\max }$ values represented the maximum contractile response induced by $\mathrm{ACh}$. Median effective concentration $\left(\mathrm{EC}_{50}\right)$ was obtained from the LCR of isolated tracheal [24].

Competitive or noncompetitive antagonism was evaluated from the rightward shift of the ACh on LCR curve, depression of the maximum response, and the Lineweaver-Burk double-reciprocal plot (DRP). Competitive antagonism, a right-shifted curve is parallel to the agonistonly curve, and the maximal response is obtainable even in the presence of the antagonist. In non-competitive antagonism, a right-shifted curve is not parallel to the agonist-only curve, and the maximal response is unattainable in the presence of the antagonist [24]

A DRP of the contractile response $(1 / R, y$-axis) was plotted against the ACh concentration $(1 /[\mathrm{ACh}], \mathrm{x}$-axis), producing a straight line with positive and negative intercepts on the $y$-axis and $\mathrm{x}$-axis, respectively. In competitive antagonism, a plot yields straight lines which have the same intercept on y-axis, while with non-competitive antagonism, a plot shows the same trend as competitive antagonism (i.e., straight lines), but the intercepts do not. The $y$-intercept was calculated from the straight line equation: Linearity over the ACh concentration was evaluated by quantification of the mean linear regression of the five replicates and calculation of the correlation coefficient $\left(\mathrm{R}^{2}\right)$ [24].

\section{Statistical analysis}

$-\log \mathrm{EC}_{50}$ and $\mathrm{R}_{\max }$ were analyzed using SPSS 17 version. The contractile responses to cumulative ACh were analyzed using one-way analysis of variance followed by a Tukey post-hoc test. All data are presented as mean \pm standard error of the mean and $p<0.05$ were considered significant.

\section{RESULTS}

The effect of EECFL on isolated guinea pig tracheal to the contraction induced by agonist compound could be observed through the changes of isolated tracheal smooth muscle contraction \% response with the addition of agonist concentration, ACh $\left(10^{-8}-10^{-3} \mathrm{M}\right)$ on tracheal organ.

Series concentration of ACh-induced the contraction on guinea-pig isolated tracheal smooth muscle. Response percentage of tracheal smooth muscle increased with the addition of ACh concentration. The maximum ACh concentration for tracheal smooth muscle contraction was $10^{-3} \mathrm{M}$. The next given concentration $\left(3 \times 10^{-3} \mathrm{M}\right)$ was not change the percentage of smooth muscle contraction (Fig. 1).

While the end of contraction from each treatment showed 100\% contraction. From the Sigmoid graph, it could be concluded that the addition of pugun tano ethanolic extract resulted antagonist effect on ACh-induced contraction.

Inhibition of contraction by the extracts was confirmed by comparing the value of $\mathrm{pD}_{2}\left(-\log \mathrm{EC}_{50}\right)$ in Fig. 2 and it showed that the addition of EECFL 1, 2, and $4 \mathrm{mg} / \mathrm{ml}$ resulted the decrease of $\mathrm{pD}_{2}$ value of $\mathrm{ACh}$ $(p<0.05)$. While $0.5 \mathrm{mg} / \mathrm{ml} \mathrm{EECFL} \mathrm{concentration} \mathrm{showed} \mathrm{not} \mathrm{different} \mathrm{of}$ $\mathrm{pD}_{2}$ value compared to the control. This study shows that EECFL at 1,2 , and $4 \mathrm{mg} / \mathrm{ml}$ concentration occur inhibitory effect on tracheal smooth muscle contraction-stimulated by ACh. Increasing concentration of the extract further reduces the potential agonists induce tracheal smooth muscle contraction. These results demonstrate the inhibitory effect of the EECFL is dose dependent manner.

The results of this study indicate that the contraction induced by ACh is significantly inhibited by EECFL at the concentrations of 1 , 2 , and $4 \mathrm{mg} / \mathrm{ml}$. Tissue incubation with varying concentrations of EECFL before contractions gradually by ACh produces right-shifts contraction curve (Fig. 1) without causing a decrease in maximal contraction $\left(\mathrm{R}_{\max }\right)$ (Table 1). Right-shifts contraction curve indicates that it takes a greater amount of ACh to produce the same effect of contraction due to the obstacles made by the extract. This inhibition does not lowering the ability of ACh to achieve maximum contraction. Both of these results indicate that EECFL occurs the ability to inhibit contraction of ACh.

To find out how the characteristic antagonist of the extracts uses DRP analysis of ACh. DRP provides an easy search antagonism mechanism of natural ingredients such as extracts. DRP results (Table 1 ) shows the regression equation of the average ACh contraction and ACh+EECFL, $\mathrm{y}$-intercept, and correlation coefficient. The $1 / \mathrm{y}$-intercept average value of each extract was 0.013 (Fig. 3, Table 3). The value is not different from the intercept of ACh (control), it can be concluded that the addition of the EECFL resulting competitive antagonist effect on the contraction induced by ACh.

\section{DISCUSSION}

ACh administrations have increased tracheal smooth muscle contraction through ACh- $\mathrm{M}_{3}$ receptor stimulation [25-27]. ACh-M receptors expressed in various types of cells and this receptor cellular signal is mediated by ACh. These receptors play an important role in

Table 1: EECFL on ACh-induced contractile response in isolated guinea pig tracheal ring

\begin{tabular}{lllll}
\hline Solution & Concentration $(\mathbf{m g} / \mathbf{m l})$ & $\mathbf{E C}_{\mathbf{5 0}}(\mathbf{m g} / \mathbf{m l})$ & $\mathbf{R}_{\text {max }}(\mathbf{\%})$ & $\mathbf{R}^{2}$ \\
\hline Krebs & - & $6.33 \times 10^{-7}$ & $100 \pm 0.00$ & 0.011 \\
EECFL & 0.5 & $1.96 \times 10^{-6 *}$ & $100 \pm 0.00$ & 0.013 \\
& 1.0 & $3.63 \times 10^{-6 *}$ & $99.34 \pm 0.46$ & 0.013 \\
& 2.0 & $5.07 \times 10^{-6 *}$ & $98.26 \pm 1.14$ & 0.954 \\
& 4.0 & $1.30 \times 10^{-5 *}$ & $97.76 \pm 0.64$ & 0.990 \\
\hline
\end{tabular}

$\mathrm{EC}_{50}$ was obtained from concentration-response curve of ACh and was taken as the concentration required to elicit $50 \%$ drop in the maximum contraction. Value for $\mathrm{R}_{\max }$ represent mean \pm SEM of five determination, $\mathrm{R}_{\max }$ and $\mathrm{EC}_{50}$ value were analyzed by one-way anova and Tukey post-hoc test. ${ }^{*} \mathrm{p}<0.05 ;$ significant difference from $\mathrm{ACh}$ alone (control). ACh: Acetylcholine, EC50: Median effective concentration, EECFL: Ethanolic extract of Curanga fel-terrae (pugun tano) leaves 


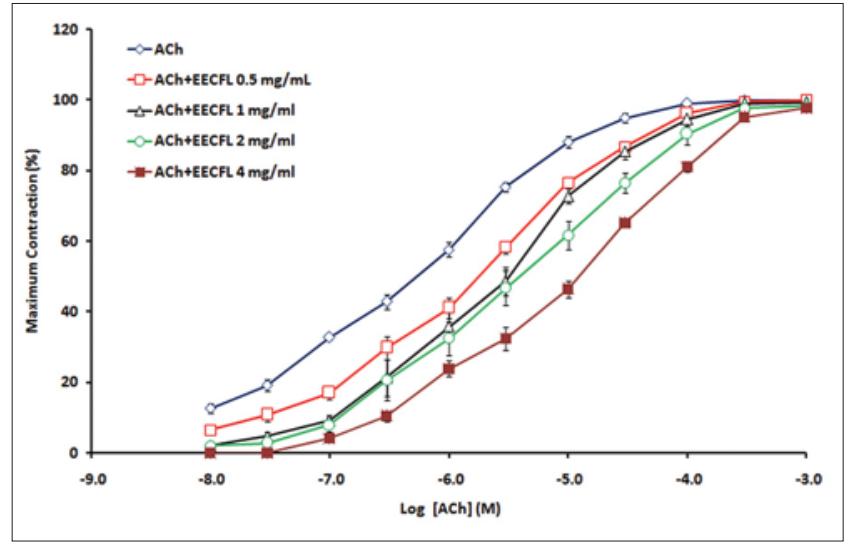

Fig. 1: Effect of ethanolic extract of Curanga fel-terrae (pugun tano) leaves on acetylcholine-induced contractile response in isolated guinea pig tracheal ring. Data presented as mean \pm standard error of mean from $n=5$

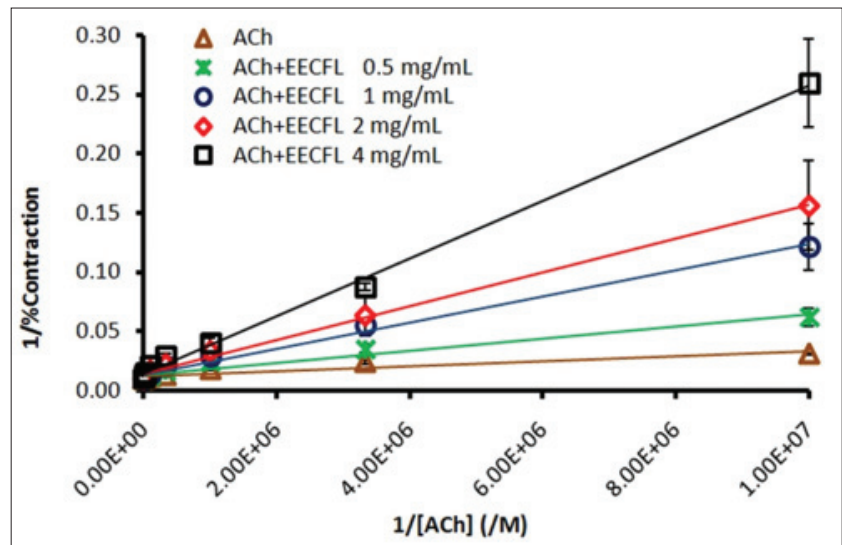

Fig. 3: Double-reciprocal plot of acetylcholine and extract of Curanga fel-terrae (pugun tano) leaves showing the mean linear regression. Data presented as mean \pm standard error of mean, $n=5$

controlling the physiological response of the central and peripheral nerve activity [28]

ACh- $\mathrm{M}_{3}$ receptors stimulation could activate phospholipase $\mathrm{C}$ enzyme, and enhance the formation of inositol 1,4,5-triphosphate (IP3) and diacylgycerol (DAG). Both of these compounds are the second messenger that plays an important role in increasing $\mathrm{Ca}^{2+}$ intracellular concentration $\left(\left[\mathrm{Ca}^{2+}\right]_{\mathrm{i}}\right)$. IP3 play a role in the increased $\left[\mathrm{Ca}^{2+}\right]_{\mathrm{i}}$ through IP3 receptor activation on sarcoplasmic reticulum so that stimulating the release of $\mathrm{Ca}^{2+}$ deposits to the cytosol. DAG activate influx of calcium via opening calcium channels in cell membranes. Increasing levels $\left[\mathrm{Ca}^{2+}\right]$ modulates calcium bond with calmodulin which will activating myiosin light chain kinase (MLCK). MLCK activation results are cross-linking between actin and myosin. The bond formation between myosin and actin and this may lead to contraction of the smooth muscle $[26,29]$.

Stimulation of ACh- $\mathrm{M}_{3}$ receptor on the smooth muscle of the airways can cause airway disorders such as bronchoconstriction and increased mucus production from the submucosal glands [18,30-32]. It is known that human muscarinic receptor is predominantly expressed in smooth muscle cells, epithelial cells, and fibroblasts [28].

Inhibition of ACh-M reseptor induced contraction by extract indicated that the chemical compounds contained in the extracts possess work at these receptors. Several compounds have been reported posses relaxation effect on smooth muscle muscarinic mediated-receptor such as flavonoid. Galangin, flavonoids have an inhibitory effect on bladder

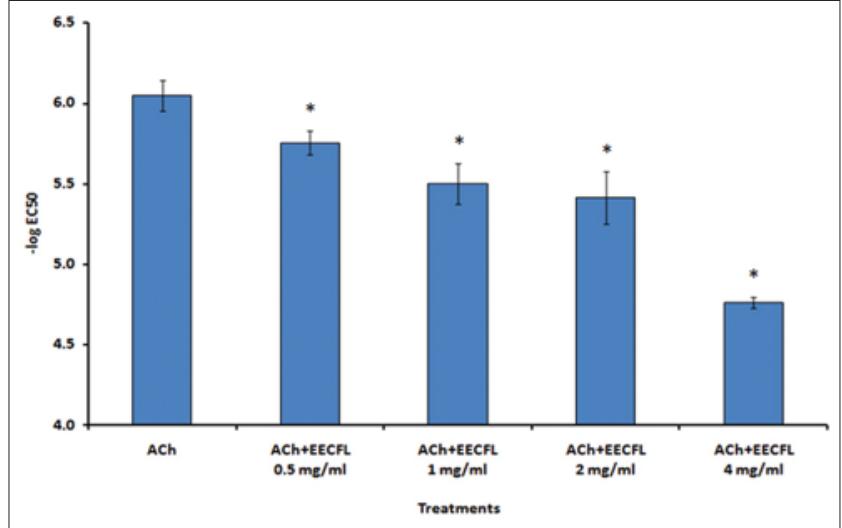

Fig. 2: $-\log \mathrm{EC}_{50}$ of acetylcholine with ethanolic extract of Curanga fel-terrae (pugun tano) leaves treatment. Data presented as mean \pm standard error of mean, $n=5 ;{ }^{*} p<0.05$, significant difference of acetylcholine alone at corresponding concentration

smooth muscle contractility [33]. Flavonoids possess antagonist activity on $\mathrm{ACh}^{-\mathrm{M}_{3}}$ receptor $[34,35]$. Steroidal saponins have bronchial asthma inhibitory via inhibition of mediator release such as prostaglandins, histamine, serotonin and bradykinin [36]. Mahapatra and Pradhan also reported that alkaloids, flavonoids, saponins, tannins, polyphenol antioxidant, and coumarins like biologically active compounds that might be responsible for the anti asthmatic activity [37]. Relevance to that result, C. fel-terrae on this study also contain flavonoids, saponins, steroids, and triterpenes. Further research is needed to determine the chemical compounds of which responsible for the inhibitory effect of ACh-muscarinic-3 receptor.

\section{CONCLUSION}

The EECFL showed competitive antagonist effect on ACh-muscarinic-3 receptor.

\section{ACKNOWLEDGMENT}

The authors are thankful to Directorate of Higher Education, Ministry of Research, Technology and Education, Republic of Indonesia for funding this research (Fundamental Research Grant 2013). We are also thankful to Ms. Diah Rahmadani and Ms. Andhorra Michi for laboratory technical assistance.

\section{REFERENCES}

1. van Valkenburg JL, Bunyapraphatsara N, editors. Plant Resources of South-East Asia No. 12 (2): Medicinal and Poisonous Plants 2. Leiden: Backhuys Publishers; 2001.

2. Zou JM, Wang LS, Niu, XM, Sun HD, Guo YJ. Phenylethanoid glycosides from Picria fel-terrae Lour. J Integr Plant Biol 2005:47(5):632-6.

3. Huang Y, De Bruyne T, Apers S, Ma Y, Claeys M, Vanden Berghe D, et al. Complement-inhibiting cucurbitacin glycosides from Picria felterrae. J Nat Prod 1998;61(6):757-61.

4. Huang Y, De Bruyne T, Apers S, Ma Y, Claeys M, Pieters L, et al. Flavonoid glucuronides from Picria fel-terrae. Phytochemistry 1999;62(8):1701-3.

5. Fang H, Ning DS, Liang XY. Studies on technology optimization for extracting triterpenoid saponins from Picria fel-terrae by multi-target grading method. J Chin Med Mater 2009;32(12):1902-5.

6. Wang LS, Li SH, Zou JM, Guo YJ, Sun HD. Two new triterpenoids from Picria fel-terrae. J Asian Nat Prod Res 2006;8(6):491-4.

7. Patilaya P, Husori DI. Preliminary study on the anthelmintic activity of the leaf ethanolic extract of Indonesian Curanga fel-terrae (Lour.) Merr. Int J Pharm Tech Res 2015;8(3):347-51.

8. Sitorus P, Harahap U, Pandapotan M, Barus T. Isolation of $\beta$-sitosterol from n-hexane extract of Picria fel-terrae Lour. Leave and study of its antidiabetic effect in alloxan induced diabetic mice. Int J PharmTech Res 2014;6(1):137-41. 
9. Harfina F, Bahri S, Saragih A. The effect of Puguntano (Curanga fel-terrae Merr.) leaves powder on diabetes mellitus patient. J Pharm Pharmacol 2012;2(1):112-8.

10. Lestari P, Hadisahputra S, Ilyas S, Satria D. Combinational effects of n-hexane extract of poguntano leaves (Picria fel-terrae Lour.) With doxorubicin on MCF-7 breast cancer cells. J Chem Pharm Res 2015;7(5):353-5.

11. Satria D, Furqan M, Hadisahputra S, Rosidah. Combinational effects of ethylacetate extract of Picria fel-terrae Lour and doxorubicin on T47D breast cancer cells. Int J Pharm Pharm Sci 2015;7(7):73-6.

12. Furqan M, Hadisahputra S, Rosidah. Effects of inhibition cell cycle and apoptosis of poguntano leaves ethylacetate extract (Picria fel-terrae Lour.) on breast cancer cells. Int J PharmTech Res 2014;6(3):1096-9.

13. Dalimunthe A, Harahap U, Rosidah, Nasution MP. Evaluation of diuretic activity of Picria fel-terrae Lour leaves extracts. Asian J Pharm Clin Res 2015;8(4):204-5.

14. Sihotang Y, Silalahi J, Hadisahputra S, Anjelisa P, Satria D. Cardioprotective effect of ethylacetate extract of poguntano (Picria felterrae Lour.) Against doxorubicin-induced cardiotoxicity in rats. Int J Pharm Clin Res 2016;8 Suppl 5:466-70.

15. WHO. Prevention of Allergy and Allergic Asthma. Geneva: WHO Document and Publication Service; 2003.

16. WHO. Asthma. Geneva: WHO Document and Publication Service 2008.

17. Ministry of Health of Republic of Indonesia. Health Profile. Jakarta: Kemenkes; 1997.

18. Gosens R, Zaagsma J, Meurs H, Halayko AJ. Muscarinic receptor signaling in the pathophysiology of asthma and COPD. Respir Res 2006;7:73.

19. Ikeda T, Anisuzzaman AS, Yoshiki H, Sasaki M, Koshiji T, Uwada $\mathrm{J}$, et al. Regional quantification of muscarinic acetylcholine receptors and $ß$-adrenoceptors in human airways. Br J Pharmacol 2012;166(6):1804-14.

20. Carr R $3^{\text {rd }}$, Koziol-White C, Zhang J, Lam H, An SS, Tall GG, et al. Interdicting $\mathrm{Gq}$ activation in airway disease by receptor-dependent and receptor-independent mechanisms. Mol Pharmacol 2016;89(1):94-104.

21. Husori DI, Riyanto S, Nugroho AE. Relaxation effect of Marmin on guinea pig tracheal smooth muscle via NO-independent mechanisms. Asian Pac J Trop Dis 2012;2:S154-8.

22. Nugroho AE, Anas Y, Arsito PN, Wibowo JT, Riyanto S, Sukari MA Effects of marmin, a compound isolated from Aegle marmelos Correa, on contraction of the guinea pig-isolated trachea. Pak J Pharm Sci 2011;24(4):427-33

23. Nugroho AE, Wibowo JT, Riyanto S. Marmin, a compound from Aegle marmelos Corr., Relaxes the ovalbumin induced contraction of trachea.
Int J Pharm Pharm Sci 2012;4 Suppl 1:479-84.

24. Srivastava RC, Nagappa AN. Surface Activity in Drug Action. Missouri: Elsevier Science Ltd.; 2005.

25. Plant PJ, North ML, Ward A, Ward M, Khanna N, Correa J, et al. Hypertrophic airway smooth muscle mass correlates with increased airway responsiveness in a murine model of asthma. Am J Respir Cell Mol Biol 2012;46(4):532-40.

26. Semenov I, Herlihy JT, Brenner R. In vitro measurements of tracheal constriction using mice. J Vis Exp 2012;. pii:3703.

27. Scott GD, Fryer AD. Role of parasympathetic nerves and muscarinic receptors in allergy and asthma. Chem Immunol Allergy 2012;98:48-69.

28. Karakiulakis G, Roth M. Muscarinic receptors and their antagonist in COPD: Anti-inflammatory and antiremodeling effects. Mediators Inflamm 2012;2012:409580.

29. Govindan S, Taylor CW. P2Y receptor subtypes evoke different $\mathrm{Ca} 2$ signals in cultured aortic smooth muscle cells. Purinergic Signal 2012;8(4):763-77.

30. Roux E, Molimard M, Savineau JP, Marthan R. Muscarinic stimulation of airway smooth muscle cells. Gen Pharmacol 1998;31(3):349-56.

31. Eglen RM, Hegde SS, Watson N. Muscarinic receptor subtypes and smooth muscle function. Pharmacol Rev 1996;48(4):531-65.

32. Villetti G, Pastore F, Bergamaschi M, Bassani F, Bolzoni PT, Battipaglia L, et al. Bronchodilator activity of (3R)-3-[[[(3fluorophenyl)[(3,4,5-trifluorophenyl)methyl]amino] carbonyl]oxy] 1-[2-oxo-2-(2-thienyl)ethyl]-1-azoniabicyclo[2.2.2]octane bromide (CHF5407), a potent, long-acting, and selective muscarinic M3 receptor antagonist. J Pharmacol Exp Ther 2010;335(3):622-35

33. Dambros $M$, van Deutekom $M$, de Jongh $R$, van Koeveringe GA, De Mey JG, van Kerrebroeck P. The inhibitory effect of the flavonoid galangin on urinary bladder smooth muscle contractility is mediated in part by modulation of $\mathrm{Ca} 2$ release from intracellular stores. Planta Med 2005;71(10):962-4.

34. Innocenti G, Dall'Acqua S, Minesso P, Budriesi R, Micucci M, Chiarini A. Evaluation of muscarinic M3-receptor antagonism of Solenostemma argel leaves. Planta Med 2010;76:634.

35. Patil DS, Ahale SV, Surana SJ. Evaluation of antiasthmatic and antianaphylactic activity of Balanites aegyptiaca (Delile) (Balanitaceae). Asian J Pharm Clin Res 2011;4(1):52-5.

36. Speroni E, Cervellati R, Innocenti G, Costa S, Guerra MC, Dall'Acqua S, et al. Anti-inflammatory, anti-nociceptive and antioxidan activities of Balanites aegyptiaca (L.) Delile. J Ethnopharmacol 2005;98(1-2):117-25

37. Mahapatra PK, Pradhan D. Relaxant effects of Limonia acidissima Linn (pulp) on guinea pig tracheal chains and its possible mechanism(s). Int J Pharm Pharm Sci 2014;6(5):257-63. 